\title{
Comparative Analyze of the Traditional and Islamic Banking Impacts on Poverty
}

\author{
GULALIYEV MAYIS G., \\ $\mathrm{PhD}$, Associate professor of the Mingachevir State University, \\ 21 D.Aliyeva str Mingachevir, AZERBAIJAN
}

GURBANOVA TUNZALE T.

$\mathrm{PhD}$, Associate professor of Azerbaijan State University of Economics (UNEC), 6 str. Istiglaliyat, Baku, AZERBAIJAN

MAMMADOVA GULTEKIN G.

$\mathrm{PhD}$. Senior lecturer of Azerbaijan State University of Economics (UNEC), 6 str. Istiglaliyat, Baku, AZERBAIJAN

TAGIYEVA NIGAR S. PhD., Associate professor of Azerbaijan State University of Economics (UNEC), 6 str. Istiglaliyat, Baku, AZERBAIJAN

ALIKHANLI YEGANA S.

Candidate for $\mathrm{PhD}$ degree of the Cooperation University, Azercell Telecom. Najaf Narimanov str., 93 Baku, AZERBAIJAN

ABDULLAYEV ELVIN S.

Candidate for PhD degree of the Azerbaijan State University of Economics (UNEC), 6 str. Istiglaliyat, Baku, AZERBAIJAN Azercell Telecom.

\begin{abstract}
The paper examines comparatively the impact of the financial system development on the poverty rate in three countries, in Azerbaijan, Turkey, and Iran. The authors have calculated aggregately all four aspects of financial development by developing four new indices. The effects of these indicators on poverty, as well as the effects of the annual change of these indicators on the annual change in the poverty rate, were analyzed by the OLS method. The econometric analysis used to check the stationarity of the time series, the cointegration method, and the ADF test. The main result is that the financial system has a weak effect on poverty in Azerbaijan, where traditional banking is fully implemented, and in Turkey, where Islamic banking is partially implemented. However, in Iran, where only Islamic banking is practiced, the indices of the financial system's efficiency and stability have a strong negative impact on poverty.
\end{abstract}

Key-Words: traditional banking; Islamic banking; financial system; poverty reduction; access to the financial system; depth of the financial system; efficiency of the financial system; the stability of financial system

Received: August 5, 2020. Revised: January 23, 2021. Accepted: February 8, 2021. Published: February 16, 2021.

\section{Introduction}

Among the Millennium Development Goals announced by the UN in 2015 is the goal of halving poverty in the near future. To achieve this goal, including the mutual development of all sectors of the economy it is necessary to develop the financial and banking system. The development of the financial system as a whole implies the development of all its aspects, including access to the financial system and the depth of financial systems. Each of these aspects identified by the World Bank for the development of financial systems reflects the specific nature of the 
financial system. Each of these aspects may be directly or indirectly related to the causes of poverty, such as the slowdown in economic growth and unemployment. For example, the shallower the financial system, the smaller the volume of loans to individuals and private businesses. This means less investment in the economy. Poor access to banking systems also weakens access to its services.

The impact of financial systems on economic development and the development of society as a whole and people's behavior has always been a serious topic of discussion. Financial systems are the central nervous system of the economy. This system includes commercial banks, insurance companies and other components. The financial system allows for the implementation of investment projects by attracting savings from various sources and distributing them among economic entities. Of course, all components of the financial system also benefit from this activity. Among the components of the financial system, banks play an important role in economic and socio-economic development.

The emergence of Islamic banking and its growing application, even in non-Islamic countries, makes it necessary to assess the impact of such banking on economic development. Although religious and secular beliefs underlie the application of different financial systems, comparing the effects of the economic effects of such different systems also has a significant impact on their future application. For example, if the application of Islamic banking was purely religious in nature, and if the application of such a system had only had a negative effect on economic growth or the socio-economic situation, then the grounds for expanding its application would have been weakened. Also, if traditional banking had only provided a basis for development, it would not have been possible to replace it in part or in whole with Islamic banking. Therefore, it is of great scientific and practical importance to assess the impact of various economic effects of Islamic banking and traditional banking, in particular, on economic growth and socio-economic spheres. Most people with Islamic faith do not use traditional banks' services, as well as Islamic banking is not practiced in most countries. This fact causes large amounts of money to be left out of the economy in these countries. This limits the spread of financial systems among the Muslim population and has a negative impact on household incomes. On the other hand, high-interest rates and the instability of financial systems in some countries with traditional financial systems have a negative impact on public confidence in financial systems. The main practical significance of this work is to substantiate the impact of Islamic banking on poverty reduction.

\section{Literature review}

Researches on the relationship between the financial sector and economic growth are common in the economic literature. Many economists (e.g. McKinnon [1]; Shaw [2]) believe that the development of the financial sector has a positive effect on the growth of production. That is why the government's policy of limiting high interest rates or creating high savings can weaken the development of the financial sector and thus have a negative impact on economic growth. It should be noted that researchers do not have an unequivocal approach to the impact of the financial sector on economic growth. Pagano's [3] endogenous model uses the AK model in the Cobb-Douglas function. In this model, economic growth depends on the percentage of savings that affect investment. One of the channels of the financial sector's impact on economic growth is the concentration of savings on investment. For example, a study by Berthelemy and Varoudakis [4] found that economic growth rates depend on the number of banks and the level of competitiveness in the financial sector. Some relevant studies can be found in [25] and [26] .

The socio-economic effects of the financial sector, including the impact on poverty, have not been extensively studied empirically. However, such studies are on the rise. The studies of Jalilian and Kirkpatrick [5]; Jeanneney and Kpodar [6], Quartey [7]; Beck et al. [8], Honohan and Beck [9] and others do not fully confirm the results obtained in the theoretical literature on the socio-economic effects of the financial sector. Thus, theoretical research confirms that the development of the financial sector can play a role in reducing income inequality. According to theoretical research, the development of the financial sector can indirectly have a positive impact on poverty reduction by supporting economic growth.

However, there is not much research on the impact of the financial sector on poverty reduction. On the other hand, there are significant differences between the results of such a limited number of studies. The main focus is on the mechanism of the financial sector's impact on poverty. The question is can we confirm that the effects of the financial sector as a whole (or its some components) on economic growth subsequently lead to poverty reduction. Some researchers, such as Todaro [10], argue that while economic progress stimulates economic growth, it does not always improve the living conditions of the poor. On the other hand, the different nature of the 
relationship between the development of the financial sector and the level of poverty in the example of different countries casts doubt on the universal relationship between the financial sector and the level of poverty. Such differences may also be due to conceptual differences in the nature of the financial sector itself. In other words, in the banking sector, which forms the basis of the financial sector, is there any conceptual difference between Islamic banking and traditional banking, from the impact on poverty viewpoint?

The problems of the socio-economic impact of the development of financial systems have been extensively studied in the economic literature. However, such studies examine the socio-economic impacts of the four components of the development of financial systems. Because there is no research on the socio-economic consequences of these aspects as an aggregate indicator. Even studies devoted to the socio-economic consequences of individual indicators do not yield universal results. For example, in Honohan [11], Perez-Moreno [12], DonouAdonsou, and Sylwester [13], and other studies, the effects of sub-indicators included in the aspect of financial depth on poverty have been substantially different. A study by Honohan [11] confirms the negative impact of financial depth on poverty, a study by Perez-Moreno [12] confirms the positive effect of the relationship between these two indicators in some cases, and a study by Donou-Adonsou and Sylwester [13] confirms a positive effect.

A study by Mookerjee and Kalipioni [14] examined the effects of some components of access to financial systems on household income inequality. The result is that there is a significant correlation between the increase in bank branches and the Gini index. Research by Akhter and Daly [15] shows that the development of financial systems has a positive effect on poverty reduction. However, financial instability of financial systems increase poverty. However, Guillaumont and Kpodar [16] argue that the development of financial systems as a whole has a negative impact on the living standards of the poorest and poorest sections of the population as they increase consumer spending.

The role of financial systems in the development of the economy as a whole is also claimed in a study conducted by Sanusi [17]. According to him, the financial system not only performs the function of mutual payments between economic entities and the provision of loans, but also delivers real financial resources to consumers. According to a study conducted by Gazi Salah Uddin et al. [18] on the example of Bangladesh, there is a cause-and-effect relationship between the development of the banking sector and poverty reduction. The study was conducted on the basis of data covering the period 1976-2010. In the case of Nigeria, this problem has been studied by Onwuka and Nwadiubu [24] using VECM analysis of data for 1986-2016, researchers conclude that poverty reduction occurs as private sector lending increases. The ratio of M2 to GDP, the ratio of loans to the private sector to GDP, and the per capita income of households were used as indicators of financial sector development.

The economic literature uses a variety of indicators, related to the financial institutions and poverty rates, to assess the impact of financial institutions on poverty. For example, Quartey [7], Uddin et al. [18] accept "per capita consumption expenditure in households" as an indicator of poverty. Honohan [9], Jalilian and Kirkpatrick [5], Beck et al. [8] and others have taken M3 and private sector lending (DC) as indicators of financial system development. In the study of Gulaliyev et al. [27], a banking stability indicator (BSI) was calculated by using the minimax normalization method. The composite index was used to analyse the financial stability of the banking sector in 29 countries and to build a risk map based on their national basic economic indicators.

\section{Methods}

In our study, we will take the indicator of "per capita household final consumption expenditure" as the level of poverty. According to the World Bank's definition household final consumption expenditure (formerly private consumption) is the market value of all goods and services, including durable products (such as cars, washing machines, and home computers), purchased by households. It excludes purchases of dwellings but includes imputed rent for owner-occupied dwellings. It also includes payments and fees to governments to obtain permits and licenses. Here, household consumption expenditure includes the expenditures of non-profit institutions serving households, even when reported separately by the country. Data are in current U.S. dollars.

As an indicator of the development of financial systems, its four aspects - 1) the index of access to financial systems $\left.\left(F \dot{\mathrm{I}} A \dot{\mathrm{I}}_{i t}\right), 2\right)$ the index of depth of financial systems $\left.\left(F \dot{\mathrm{I}} D \dot{\mathrm{I}}_{i t}\right) ; 3\right)$ financial systems efficiency index $\left.\left(F \dot{\mathrm{I}} E \dot{\mathrm{I}}_{i t}\right) ; 4\right)$ the stability index of financial systems $\left(F \dot{\mathrm{I}} S \dot{\mathrm{I}}_{i t}\right)$ will be included in the model separately, and then as an integrated index of financial system development $\left(F S D \dot{\mathrm{I}}_{i t}\right)$

The access to financial institutions index covers 36 subindexes (GFDR, 2018). Based on these indicators, a composite indicator, such as the Financial Institutions Access Index (FIAI), can be calculated to 
assess the level of development of a country's financial system. This indicator can be obtained by indexing and summing the same weight of each of the above sub-indices, i.e.

$$
F I A I_{i, t}=\frac{1}{n} \sum_{j}^{n}\left(\frac{F I A_{i, j, t}-F I A_{t, \min }}{F I A_{t, \text { max }}-F I A_{t, \text { min }}}\right)
$$

Where, $F I A I_{i, t}-$ Index of Access to Financial Institutions of country $i$ in year $t ; F I A_{i, t, j}$ - indexed value of subindex $i$ by subindex $j$ in year $t ; F I A_{t, \min }$ - the minimum possible value of sub-index $j$ for the financial system of countries in year $t ; F I A_{t, \max }-$ the maximum possible value of sub-index $j$ for the financial system of countries in year $t$. For all subindexes, measured in percent, we can assume $F I A_{t, \min }=0$ and $F I A_{t, \max }=100$.

For the 6th, 7th, and 8th subindex, $F I A_{t, \min }=0$, a $F I A_{t, \max }$ can be taken, respectively, 100,000, 1000, and 100,000 . We can compare the effectiveness of the banking systems of several countries, according to FIAI, using subindexes in which the principles of Islamic and traditional banking models may differ.

The Depth Index of Financial Institutions consists of 14 subindexes. Using these subindexes, the Financial Institutions Depth Index (FIDI) can be calculated. Such a composite index can be expressed by the formula:

$$
F I D I_{i, t}=\frac{1}{n} \sum_{j}^{n}\left(\frac{F I D_{i, j, t}-F I D_{t, \text { min }}}{F I D_{t, \text { max }}-F I D_{t, \text { min }}}\right)
$$

Where, $F I D I_{i, t}$ - Index of Access to Financial Institutions of country $i$ in year $t ; F I D_{i, t, j}-$ is the indexed value of subindex $i$ by subindex $j$ in year $t$; $F I D_{t, \min }$ - the minimum possible value of subindex $j$ for financial systems in year $t ; F I D_{t, \max }$ - the maximum possible value of subindex $j$ for financial systems in year $t$.

For all subindexes, measured as a percentage, we can assume $F I D_{t, \min }=0$ and $F I D_{t, \max }=100$. We can compare the efficiency of several countries' banking systems by FIDI using subindexes in which the principles of Islamic and traditional banking models may differ.

The effectiveness of the financial institutions index contains ten subindices. Based on these indicators, we can calculate the composite Financial Institutions Effectiveness Index (FIEI) as follows:

$$
F I E I_{i, t}=\frac{1}{n} \sum_{j}^{n}\left(\frac{F I E_{i, j, t}-F I E_{t, \text { min }}}{F I E_{t, \text { max }}-F I E_{t, \text { min }}}\right)
$$

Where, $F I E I_{i, t}$ - Index of Access to Financial Institutions of country $i$ in year $t ; F I E_{i, t, j}-$ is the indexed value of subindex $i$ by subindex $j$ in year $t$; $F I E_{t, \min }$ - the minimum possible value of sub-index $j$ for the financial systems of countries in year $t$; $F I E_{t, \max }-$ is the maximum possible value of subindex $j$ for the financial systems of countries in year $t$. For all subindexes, which are measured in percent, we can consider

$$
F I E_{t, \min }=0 \text { and } F I E_{t, \max }=100 .
$$

The stability of financial institutions can be calculated using seven subindexes. For a comparative analysis of the stability of financial institutions based on these indicators, a composite index - the Financial Institutions Stability Index (FISI) - can be calculated as follows:

$$
F I S I_{i, t}=\frac{1}{n} \sum_{j}^{n}\left(\frac{F I S_{i, j, t}-F I S_{t, \text { min }}}{F I S_{t, \text { max }}-F I S_{t, \text { min }}}\right)
$$

Where, $F I S I_{i, t}-$ Stability Index of Financial Institutions of country $i$ in year $t ; F I S_{i, t, j}-$ indexed value of subindex $i$ by subindex $j ; F I S_{t, \text { min }}$ - the minimum possible value of subindex $j$ for the financial systems of countries in year $t ; F I S_{t, \max }-$ the maximum possible value of sub-index $j$ for the financial systems of countries in year $t$. For all subindexes, which are measured in percent, we can consider $F I S_{t, \min }=0$ and $F I S_{t, \max }=100$. We can compare the effectiveness of several countries' banking systems by FISI using subindexes in which the principles of Islamic and traditional banking models may differ.

The Financial Development Composite Index (FDCI) can be calculated based on the four indices listed above as:

$$
F D C I_{i t}=F I A I_{i t}+F I D I_{i t}+F I E I_{i t}+F I S I_{i t}
$$

The relationship between these indicators will be compared in the case of three countries - Azerbaijan (with traditional banking only), Turkey (with traditional and Islamic banking) and Iran (with Islamic banking only) by using OLS method, unlike [22], [24] etc. The econometric analysis used to check the stationarity of the time series, the cointegration method, and the ADF test. .

Therefore, we accept the following hypotheses:

1. $\mathrm{H}_{0}: a_{i 1}=0$; i.e. there are not any regression relationship between a) $F \dot{\mathrm{I}} A \dot{\mathrm{I}}_{i t}$; b) $F \dot{\mathrm{I}} D \dot{\mathrm{I}}_{i t}$; c) $F \dot{\mathrm{I}} E \dot{\mathrm{I}}_{i t}$; d) $F \dot{\mathrm{I}} \dot{\mathrm{I}}_{i t}$ e) $F S D \dot{\mathrm{I}}_{i t}$, as weel as their annual changes and $\mathrm{POV}_{i t}$, as well as its annual changes, i.e. $\Delta \mathrm{POV}_{i t}$. 2. $\mathrm{H}_{1}: a_{i 1} \neq 0$; there are regression relationship between a) $F \dot{\mathrm{I}} A \dot{\mathrm{I}}_{i t}$; b) $F \dot{\mathrm{I}} D \dot{\mathrm{I}}_{i t}$; c) $F \dot{\mathrm{I}} E \dot{\mathrm{I}}_{i t}$; d) $F \dot{\mathrm{I}} S \dot{\mathrm{I}}_{i t}$ e) $F S D \dot{\mathrm{I}}_{i t}$, as well as their annual changes and $\mathrm{POV}_{i t}$, as well as its annual changes, i.e. $\triangle \mathrm{POV}_{i t}$.

In this case, we will use a single regression relationship as $\quad \mathrm{Y}_{i t}=a_{i 0}+a_{i 1} * X_{i t}+\varepsilon_{i t}$ (6) Here $\left.\mathrm{Y}_{i t^{-}} P O V_{i t}, X_{i t}-\mathrm{a}\right) F \dot{\mathrm{I}} A \dot{\mathrm{I}}_{i t}$; b) $F \dot{\mathrm{I}} D \dot{\mathrm{I}}_{i t}$; c) $F \dot{\mathrm{I}} E \dot{\mathrm{I}}_{i t}$; c) $F \dot{\mathrm{I}} S \dot{\mathrm{I}}_{i t}$ d) $F S D \dot{\mathrm{I}}_{i t}$ can be any of the indicators. For their annual changes the single regression relationship between these indicators will be as

$$
\Delta \mathrm{Y}_{i t}=a_{i 0}+a_{i 1} * \Delta X_{i t}+\eta_{i t}
$$


Here $\Delta \mathrm{Y}_{i t}-\Delta \mathrm{POV}_{i t}, \Delta X_{i t}-$ a) $\Delta F \dot{\mathrm{I}} A \dot{\mathrm{I}}_{i t} ;$ b) $\Delta F \dot{\mathrm{I}} D \dot{\mathrm{I}}_{i t}$; c) $\Delta F \dot{\mathrm{I}} E \dot{\mathrm{I}}_{i t} ;$ d) $\Delta F \dot{\mathrm{I}} S \dot{\mathrm{I}}_{i t}$ e) $\Delta F S D \dot{\mathrm{I}}_{i t}$ can be any of these indicators.

The research algorithm is designed as follows:

The time series of the dependent and independent indicators involved in the study should be checked by the Augmented Dickey-Fuller (ADF) test to checking stationarity. The ADF test is performed for all three models, i.e. a) without "intercept" and "trend", i.e. $\Delta y_{t}=\gamma * y_{t-1}+v_{t} ;$ b) with "intercept" but no "trend", i.e. $\Delta y_{t}=\alpha+\gamma * y_{t-1}+v_{t}$; c) which "intercept" and trend, i.e. $\Delta y_{t}=\alpha+\lambda * t+\gamma *$ $y_{t-1}+v_{t}$ will be taken for the models. If there is not stationarity between two variables we will check their cointegration.

We will use critical values for $\boldsymbol{\tau}_{\boldsymbol{c}}$ proposed by Davidson and MacKinnon (1993) and given in Table 1 for the calculations.

Table 1

Critical values for $\boldsymbol{\tau}_{c}$ for Dickey-Fuller test

\begin{tabular}{|c|l|l|l|}
\hline & $1 \%$ & $5 \%$ & $10 \%$ \\
\hline $\boldsymbol{\Delta} \boldsymbol{y}_{\boldsymbol{t}}=\boldsymbol{\gamma} * \boldsymbol{y}_{\boldsymbol{t}-\mathbf{1}}+\boldsymbol{v}_{\boldsymbol{t}}$ & -2.56 & -1.94 & -1.62 \\
\hline $\begin{array}{c}\Delta \boldsymbol{y}_{\boldsymbol{t}}=\boldsymbol{\alpha}+\boldsymbol{\gamma} * \boldsymbol{y}_{\boldsymbol{t}-\mathbf{1}}+\boldsymbol{v}_{\boldsymbol{t}} \\
\boldsymbol{\Delta} \boldsymbol{y}_{\boldsymbol{t}}=\boldsymbol{\alpha}+\boldsymbol{\lambda} * \boldsymbol{t}+\boldsymbol{\gamma} * \boldsymbol{y}_{\boldsymbol{t}-\mathbf{1}} \\
+\boldsymbol{v}_{\boldsymbol{t}}\end{array}$ & -3.96 & -2.86 & -2.57 \\
\hline Standard critical values & -2.33 & -1.65 & -1.28 \\
\hline
\end{tabular}

The Granger test will be used to test whether the relationships between stationary time series or cointegration time series are cause-and-effect in the Granger sense. Note that in some of the studies reviewed above, the ARDL model was used.

\section{Results}

It should be noted that currently there is only traditional banking in Azerbaijan, both traditional and Islamic banking in Turkey, and only Islamic banking in Iran. The traditional and Islamic banking differ on four aspects that characterize the development of financial systems, mainly on some sub-indicators included in the indicators of "depth of financial systems", "efficiency of financial systems" and "stability of financial systems" aspects. The dynamics of the four main indices for the period 1993-2017, which we will use to conduct a comparative analysis of macroeconomic and socioeconomic impacts on these countries, is given in Table 2. These four main indices are calculated by the entitles (1) - (4). As well as the Table II also shows the annual per capita expenditures of households in these countries in US dollars that obtained from official base World Bank

Table 2

Indicators characterizing the development of financial systems and the level of poverty

\begin{tabular}{|c|c|c|c|c|c|c|c|c|c|c|c|c|c|c|c|}
\hline & \multicolumn{5}{|c|}{ Azerbaijan } & \multicolumn{5}{|c|}{ Turkey } & \multicolumn{5}{|c|}{ Iran } \\
\hline & FİAI & FİII & FİĖ & FİSI & POV & FİAI & FİDI & FİEI & FİII & POV & FİAI & FIDİ & FİEİ & FİSI & POV \\
\hline 1993 & - & 0.228 & 0.342 & 0.192 & 348.04 & - & 0.176 & 0.055 & 0.382 & 2197.30 & $\begin{array}{ll}- \\
-\end{array}$ & 0.205 & 0.011 & 0.308 & 559.57 \\
\hline 1994 & - & 0.134 & 0.190 & 0.110 & 338.39 & - & 0.174 & 0.055 & 0.336 & 1588.28 & - & 0.200 & 0.009 & 0.300 & 609.13 \\
\hline 1995 & - & 0.142 & 0.133 & 0.057 & 335.03 & - & 0.162 & 0.047 & 0.295 & 2037.53 & $\begin{array}{ll}- & - \\
\end{array}$ & 0.189 & 0.009 & 0.279 & 785.14 \\
\hline 1996 & - & 0.145 & 0.079 & 0.173 & 358.80 & $\begin{array}{lll}- & - \\
\end{array}$ & 0.182 & 0.020 & 0.213 & 2054.49 & $\begin{array}{ll}- \\
-\end{array}$ & 0.174 & 0.007 & 0.256 & 915.86 \\
\hline 1997 & -- & 0.136 & 0.229 & 0.201 & 376.48 & $\begin{array}{l}- \\
\end{array}$ & 0.198 & -0.046 & 0.221 & 2139.35 & -- & 0.186 & 0.006 & 0.250 & 945.48 \\
\hline 1998 & - & 0.126 & 0.087 & 0.181 & 449.55 & - & 0.171 & 0.028 & 0.200 & 2907.44 & - & 0.202 & 0.005 & 0.256 & 998.52 \\
\hline 1999 & - & 0.099 & 0.046 & 0.256 & 434.87 & - & 0.189 & 0.057 & 0.237 & 2720.02 & - & 0.197 & 0.015 & 0.272 & 914.86 \\
\hline 2000 & - & 0.104 & 0.088 & 0.353 & 421.96 & - & 0.182 & -0.035 & 0.244 & 2905.75 & - & 0.216 & 0.011 & 0.348 & 830.45 \\
\hline 2001 & - & 0.111 & 0.066 & 0.283 & 432.74 & - & 0.184 & -0.191 & 0.256 & 2039.16 & - & 0.245 & 0.011 & 0.402 & 958.92 \\
\hline 2002 & - & 0.112 & 0.074 & 0.319 & 479.99 & - & 0.180 & 0.054 & 0.286 & 2355.61 & - & 0.241 & 0.011 & 0.411 & 890.74 \\
\hline 2003 & - & 0.130 & 0.080 & 0.316 & 529.85 & $\begin{array}{l}- \\
-\end{array}$ & 0.169 & 0.082 & 0.334 & 3111.16 & - & 0.255 & 0.018 & 0.433 & 1001.70 \\
\hline 2004 & - & 0.145 & 0.085 & 0.332 & 583.24 & 0.344 & 0.171 & 0.086 & 0.299 & 3924.81 & 0.283 & 0.270 & 0.035 & 0.467 & 1176.29 \\
\hline 2005 & - & 0.148 & 0.070 & 0.309 & 664.84 & 0.584 & 0.189 & 0.085 & 0.285 & 4730.59 & 0.160 & 0.264 & 0.029 & 0.488 & 1337.48 \\
\hline 2006 & 0.086 & 0.156 & 0.072 & 0.342 & 917.59 & 0.379 & 0.219 & 0.082 & 0.274 & 5003.69 & 0.179 & 0.315 & 0.022 & 0.496 & 1563.97 \\
\hline 2007 & 0.086 & 0.156 & 0.080 & 0.331 & 1286.43 & 0.403 & 0.233 & 0.087 & 0.267 & 6083.07 & 0.206 & 0.330 & 0.016 & 0.513 & 2031.77 \\
\hline 2008 & 0.115 & 0.171 & 0.064 & 0.355 & 1863.90 & 0.635 & 0.232 & 0.046 & 0.253 & 6687.54 & 0.231 & 0.342 & 0.027 & 0.538 & 2381.86 \\
\hline 2009 & 0.370 & 0.191 & 0.031 & 0.206 & 2116.58 & 0.445 & 0.257 & 0.084 & 0.262 & 5603.55 & 0.255 & 0.364 & 0.035 & 0.525 & 2540.67 \\
\hline 2010 & 0.135 & 0.181 & -0.024 & 0.207 & 2299.88 & 0.439 & 0.272 & 0.071 & 0.260 & 6729.60 & 0.279 & 0.374 & 0.026 & 0.509 & 2832.71 \\
\hline 2011 & 0.103 & 0.176 & -0.001 & 0.199 & 2678.77 & 0.337 & 0.277 & 0.044 & 0.258 & 7160.32 & 0.343 & 0.373 & 0.052 & 0.537 & 3376.36 \\
\hline 2012 & 0.152 & 0.189 & 0.013 & 0.196 & 2958.86 & 0.501 & 0.288 & 0.048 & 0.261 & 7302.29 & 0.361 & 0.391 & -0.081 & 0.329 & 3779.02 \\
\hline 2013 & 0.431 & 0.207 & 0.014 & 0.220 & 3300.18 & 0.584 & 0.304 & 0.031 & 0.258 & 7750.50 & 0.391 & 0.377 & 0.055 & 0.784 & 2742.54 \\
\hline 2014 & 0.150 & 0.230 & 0.013 & 0.241 & 3585.62 & 0.365 & 0.321 & 0.026 & 0.264 & 7349.51 & 0.403 & 0.412 & 0.028 & 0.777 & 2586.94 \\
\hline
\end{tabular}




\begin{tabular}{|l|l|l|l|l|l|l|l|l|l|l|l|l|l|l|l|}
\hline 2015 & 0.234 & 0.300 & -0.064 & 0.210 & 3118.13 & 0.596 & 0.327 & 0.057 & 0.288 & 6609.55 & 0.488 & 0.491 & 0.028 & 0.833 & 2466.79 \\
\hline 2016 & 0.327 & 0.342 & -0.023 & 0.408 & 2278.32 & 0.604 & 0.338 & 0.067 & 0.289 & 6473.31 & 0.515 & 0.650 & 0.062 & 0.498 & 2594.41 \\
\hline 2017 & 0.173 & & & & 2388.16 & 0.309 & & & & 6206.25 & 0.480 & & & & 2629.01 \\
\hline
\end{tabular}

Note: Dates on FİAI, FİAI, FİII, FİSI are calculated according to the entitles (1)-(4), the dates on POV are obtained from WB (2020)

Examining the effects of financial system development indicators on household incomes through a single regression analysis, we obtain the results in the Table 3 (for Azerbaijan), in the Table 4 (for Turkey) and in the Table 5 (for Iran). Calculations show that there is a significant relationship between two aspects of Azerbaijan's financial systems, i.e. "the depth of financial systems" and "the efficiency of financial systems", and "the per capita income of households". For the other two indicators, the determination coefficient of such a relationship is much smaller and the Fsignificance is much larger than the allowable interval (0.05 for the 5\% interval). The regression analysis shows that the depth of financial systems has a positive relationship with household income, while the efficiency of financial systems has a negative relationship. Based on the data in the Table 3, we can claim that there is a kind of relationship between the indicators of depth of financial institutions $\left(\mathrm{FIDI}_{t}\right)$ and efficiency of financial institutions $\left(\mathrm{FIEI}_{t}\right)$ in Azerbaijan and per capita household expenditure $\left(\mathrm{POV}_{t}\right)$. The effect of the other two indicators characterizing the development of the financial system on the $\mathrm{POV}_{t}$ indicator is not significant.

Dependence of poverty level on financial system development indices in Azerbaijan

Table 3 $\left(\mathrm{POV}_{t}=a_{i 0}+a_{i 1} * X_{t}+\varepsilon_{i t}\right)$

\begin{tabular}{|c|c|c|c|c|}
\hline \multicolumn{5}{|c|}{$\left(\mathrm{POV}_{t}=a_{i 0}+a_{i 1} * X_{t}+\varepsilon_{i t}\right)$} \\
\hline & $\overrightarrow{\mathrm{FI} A \dot{I}_{t}}$ & $\mathrm{FIDI}_{t}$ & FIEI $\dot{I}_{t}$ & FISI $_{t}$ \\
\hline$R^{2}$ & 0.154566 & 0.473344 & 0.452185 & $2.03 \mathrm{E}-05$ \\
\hline Number of observations & 12 & 24 & 24 & 24 \\
\hline F-significance & 0.206121 & 0.000203 & 0.000319 & 0.983329 \\
\hline \multicolumn{5}{|l|}{$a_{i 0}$} \\
\hline ratio & 1875.693 & -897.484 & 1986.439 & 1324.862 \\
\hline Standard error & 446.0701 & 531.9841 & 232.4898 & 751.1231 \\
\hline t-statistics & 4.204928 & -1.68705 & 8.544199 & 1.763841 \\
\hline p-price & 0.001814 & 0.105723 & $1.95 \mathrm{E}-08$ & 0.091643 \\
\hline \multicolumn{5}{|l|}{$a_{i 1}$} \\
\hline ratio & 2660.502 & 13229.28 & -8897.07 & 60.2551 \\
\hline Standard error & 1967.643 & 2975.089 & 2087.827 & 2851.09 \\
\hline t-statistics & 1.352127 & 4.446685 & -4.2614 & 0.021134 \\
\hline p-price & 0.206121 & 0.000203 & 0.000319 & 0.983329 \\
\hline
\end{tabular}

Note: Calculated by the authors

Calculations show that only one of the indicators characterizing the financial system of Turkey - the depth of the financial system - has a positive impact on household income. Other indicators have little or no effect on household income. Table 4, which characterizes the relationship between the indicators characterizing the Turkish financial system and the per capita expenditures of households in Turkey, shows that there is a significant relationship between the depth index of Turkish financial institutions $\left(\mathrm{FIII}_{t}\right)$ and $\mathrm{POV}_{t}$. There is no significant relationships between with other indices.

In Iran, which uses only Islamic banking, the depth of financial institutions and the stability of financial institutions have a significant impact on household income. In Iran, which applies Islamic banking, there is a significant relationship between $\mathrm{POV}_{t}$ and with both FIDI $\dot{I}_{t}$, and FISI $\dot{I}_{t}$. The effect of both indicators is positive (Table 5).

\section{Table 4}

\section{Dependence of poverty level in Turkey on financial system development indices} $\left(\mathrm{POV}_{\mathrm{t}}=\mathbf{a}_{\mathrm{i} 0}+\mathbf{a}_{\mathrm{i} 1} * \mathrm{X}_{\mathrm{t}}+\varepsilon_{\mathrm{it}}\right)$

\begin{tabular}{|c|c|c|c|c|}
\hline & Fí $_{t}$ & FiD $_{t}$ & FiE $_{t}$ & FiSi $_{t}$ \\
\hline$R^{2}$ & 0.049844 & 0.776456 & 0.114283 & 0.016221 \\
\hline $\begin{array}{l}\text { Number of } \\
\text { observations }\end{array}$ & 14 & 24 & 24 & 24 \\
\hline F-significance & 0.442941 & $1.31 \mathrm{E}-08$ & 0.106157 & 0.553146 \\
\hline$a_{i 0}$ & \multicolumn{5}{|l}{} \\
\hline ratio & 5265.567 & -2933.94 & 3996.745 & 6351.409 \\
\hline
\end{tabular}




\begin{tabular}{|c|r|r|r|r|}
\hline Standard error & 1286.091 & 874.4832 & 512.9755 & 3143.319 \\
\hline t-statistics & 4.094243 & -3.35506 & 7.791298 & 2.020606 \\
\hline p-price & 0.001488 & 0.002862 & $9.13 \mathrm{E}-08$ & 0.055658 \\
\hline$a_{i 1}$ & \multicolumn{5}{|l}{} \\
\hline ratio & 2129.753 & 32971.09 & 12279.3 & -6895.03 \\
\hline Standard error & 2684.279 & 3771.773 & 7288.171 & 11448.23 \\
\hline t-statistics & 0.793417 & 8.741536 & 1.684826 & -0.60228 \\
\hline p-price & 0.442941 & $1.31 \mathrm{E}-08$ & 0.106157 & 0.553146 \\
\hline
\end{tabular}

Note: Calculated by the authors

It should be noted that, according to Tables 3,4 and 5 , the existence of the regression relationship between some indicators does not yet lead to the conclusion that such relationships are true.

\begin{tabular}{|c|c|c|c|c|}
\hline \multicolumn{5}{|c|}{$\begin{array}{l}\text { Dependence of poverty level on financial } \\
\text { system development indices in Iran } \\
\qquad\left(\mathrm{POV}_{t}=a_{i 0}+a_{i 1} * X_{t}+\varepsilon_{i t}\right)\end{array}$} \\
\hline & FİA $\dot{I}_{t}$ & FİDI $_{t}$ & $\mathrm{FIEI}_{t}$ & $\mathrm{FISI}_{t}$ \\
\hline$R^{2}$ & 0.251465 & 0.61829 & 0.003178 & 0.373987 \\
\hline $\begin{array}{c}\text { Number of } \\
\text { observations }\end{array}$ & 12 & 24 & 24 & 24 \\
\hline F-significance & 0.06772 & $5.23 \mathrm{E}-06$ & 0.793616 & 0.001497 \\
\hline \multicolumn{5}{|l|}{$a_{i 0}$} \\
\hline ratio & 1424.943 & -306.029 & 1662.581 & 115.8839 \\
\hline Standard error & 530.4563 & 358.5148 & 247.8236 & 465.379 \\
\hline t-statistics & 2.68626 & -0.8536 & 6.708729 & 0.24901 \\
\hline
\end{tabular}

\begin{tabular}{|c|c|c|c|c|}
\hline p-price & 0.019806 & 0.402524 & $9.62 \mathrm{E}-07$ & 0.805663 \\
\hline$a_{i 1}$ & \multicolumn{5}{|c|}{} \\
\hline ratio & 3080.588 & 6631.678 & 2056.441 & 3519.286 \\
\hline Standard error & 1534.302 & 1110.92 & 7765.529 & 970.7486 \\
\hline t-statistics & 2.007811 & 5.969538 & 0.264817 & 3.625332 \\
\hline p-price & 0.06772 & $5.23 \mathrm{E}-06$ & 0.793616 & 0.001497 \\
\hline
\end{tabular}

Note: Calculated by the authors

Thus, we need to make sure that the time series of the indicators for which there is a regression relationship are stationary. For this purpose, the time series of the dependent and independent indicators should be checked by the Augmented Dickey-Fuller (ADF) test. The ADF test is performed for all three models as we mentioned above.

Note that the maximum lag $=5$ will be taken to check the stationarity of the time series. As a method, the least squares method (OLS) is selected and the Schwartz information criterion is used. The hypothesis $\mathrm{H}_{0}$ for time series of the indicators is that they have a unit root. The $\mathrm{H}_{1}$ hypothesis is the rejection of $\mathrm{H}_{0}$, that is, the time series does not have a unit root. The results of the analysis conducted using the E-Views software package are given in Table 6. It can be seen from the table that none of the time series is stationary without "intercept" and "trend".

Table 6

Without the "intersection" and "inclination" of the time series of some indicators

\begin{tabular}{|c|c|c|c|c|c|c|c|}
\hline \multicolumn{8}{|c|}{$\left(\Delta y_{t}=\beta * y_{t-1}+\gamma * \Delta y_{t-1}+v_{t}\right)$ results } \\
\hline & & R-squared & coefficient & Std.error & t-statistics & probability & $\begin{array}{l}\text { MacKinnon one-sided p- } \\
\text { price }\end{array}$ \\
\hline \multicolumn{8}{|c|}{ Azerbaijan } \\
\hline \multirow[t]{3}{*}{$\mathrm{POV}_{t}$} & POV(-1) & 0.379931 & 0.067633 & 0.042362 & 1.596541 & 0.1269 & \multirow[t]{3}{*}{0.9687} \\
\hline & $\mathrm{D}(\mathrm{POV}(-1))$ & & 0.998977 & 0.270258 & 3.696376 & 0.0015 & \\
\hline & $\mathrm{D}(\mathrm{POV}(-2))$ & & -1.008867 & 0.439010 & -2.298052 & 0.0331 & \\
\hline \multirow{2}{*}{ FIDI $_{t}$} & FİDİ(-1) & 0.237944 & 0.065281 & 0.023673 & 2.757656 & 0.0121 & \multirow[t]{2}{*}{0.9974} \\
\hline & D(FİDİ(-1) & & 0.194910 & 0.139682 & 1.395381 & 0.1782 & \\
\hline FİĖ $_{t}$ & & 0.357231 & -0.345748 & 0.090455 & -3.822300 & 0.0009 & 0.0005 \\
\hline \multicolumn{8}{|c|}{ Turkey } \\
\hline $\mathrm{POV}_{t}$ & $\mathrm{POV}(-1)$ & -0.048601 & 0.020750 & 0.025725 & 0.806620 & 0.4281 & 0.8800 \\
\hline Fİ İ $_{t}$ & FİDİ(-1) & 0.038654 & 0.033209 & 0.012236 & 2.713990 & 0.0127 & 0.9972 \\
\hline \multicolumn{8}{|c|}{ Iran } \\
\hline $\mathrm{POV}_{t}$ & POV $(-1)$ & -0.061035 & 0.023926 & 0.032424 & 0.737922 & 0.4680 & 0.8673 \\
\hline \multirow[t]{2}{*}{ FíI $_{t}$} & Fídì(-1) & 0.382560 & 0.039330 & 0.027525 & 1.428878 & 0.1685 & \multirow[t]{2}{*}{0.9571} \\
\hline & $\overline{\mathrm{D} \text { (FİDİ(-1)) }}$ & & 0.859622 & 0.331713 & 2.591464 & 0.0174 & \\
\hline $\mathrm{FISI}_{t}$ & FİSİ(-1) & 0.002312 & -0.021542 & 0.057085 & -0.377372 & 0.7095 & 0.5371 \\
\hline
\end{tabular}

Note: Calculated by the authors using the eViews software package.

The results in Tables 5, 6 and 7 show that the time series of the POV indicator is not based on any of the models in which each stationary is tested in any of these countries, i.e. 1) without "intercept" and "trend"; 2) "there is an intercept" but no "trend"; 3) not stationary on models with both "intercept" and "trend". Thus, according to Tables 5 and 6 , only in 
Azerbaijan the time series of the indicator $F \dot{\mathrm{I}} E \dot{\mathrm{I}}_{t}$ is stationary.

According to Table 7, only the time series of the FisI $\dot{I}_{t}$ indicator for Iran is stationary. Even the fact that the indicators' time series have not stationarity does not give argument to claim the invalidity of their relationship. In order to verify the validity of the relationship of other indicators with $P O V_{t}$, we must check the cointegration between them. Because the time series of these indicators are not stationary.

The results of the time series of some indicators are "intersecting", but without "inclination"

Table 7

$$
\left(\Delta y_{t}=\alpha+\beta * y_{t-1}+\gamma * \Delta y_{t-1}+v_{t}\right)
$$

\begin{tabular}{|c|c|c|c|c|c|c|c|}
\hline & & R-squared & coefficient & Std. error & t-statistics & probability & MacKinnon one-sided p-price \\
\hline \multicolumn{8}{|c|}{ Azerbaijan } \\
\hline \multirow[t]{4}{*}{$\mathrm{POV}_{t}$} & $\mathrm{POV}(-1)$ & 0.421682 & 0.020797 & 0.058778 & 0.353826 & 0.7276 & \multirow[t]{4}{*}{0.9758} \\
\hline & $\mathrm{D}(\mathrm{POV}(-1))$ & & 0.937432 & 0.273534 & 3.427107 & 0.0030 & \\
\hline & $\mathrm{D}(\mathrm{POV}(-2))$ & & -0.922316 & 0.442158 & -2.085943 & 0.0515 & \\
\hline & $\mathrm{C}$ & & 97.04364 & 85.13011 & 1.139945 & 0.2693 & \\
\hline \multirow[t]{2}{*}{$\overline{F i D}_{t}$} & FİDİ(-1) & 0.023055 & 0.092341 & 0.131173 & 0.703968 & 0.4892 & \multirow[t]{2}{*}{0.9895} \\
\hline & $\mathrm{C}$ & & -0.009967 & 0.022058 & -0.451830 & 0.6560 & \\
\hline \multirow[t]{2}{*}{$\overline{F I E I}_{t}$} & FİĖं(-1) & 0.415442 & -0.462873 & 0.119815 & -3.863232 & 0.0009 & \multirow[t]{2}{*}{0.0078} \\
\hline & $\mathrm{c}$ & & 0.019691 & 0.013617 & 1.446091 & 0.1629 & \\
\hline \multicolumn{8}{|c|}{ Turkey } \\
\hline \multirow[t]{2}{*}{$\mathrm{POV}_{t}$} & $\mathrm{POV}(-1)$ & 0.035299 & -0.052811 & 0.058861 & -0.897219 & 0.3793 & \multirow[t]{2}{*}{0.7713} \\
\hline & $\mathrm{C}$ & & 403.5116 & 291.7147 & 1.383241 & 0.1805 & \\
\hline \multirow{2}{*}{$\mathrm{FIIII}_{t}$} & FİDİ(-1) & 0.045648 & 0.053617 & 0.053498 & 1.002226 & 0.3276 & \multirow[t]{2}{*}{0.9951} \\
\hline & $\mathrm{C}$ & & -0.004745 & 0.012096 & -0.392294 & 0.6988 & \\
\hline \multicolumn{8}{|c|}{ Iran } \\
\hline \multirow[t]{2}{*}{$\mathrm{POV}_{t}$} & POV $(-1)$ & 0.040741 & -0.062719 & 0.064884 & -0.966627 & 0.3442 & \multirow[t]{2}{*}{0.7482} \\
\hline & $\mathrm{C}$ & & 192.9038 & 126.2623 & 1.527802 & 0.1408 & \\
\hline \multirow[t]{3}{*}{$\mathrm{FIDI}_{t}$} & Fİi்i(-1) & 0.432332 & 0.147334 & 0.087952 & 1.675177 & 0.1103 & \multirow[t]{3}{*}{0.9992} \\
\hline & D(Fİंi்(-1) & & 0.676357 & 0.355878 & 1.900534 & 0.0726 & \\
\hline & $\mathrm{C}$ & & -0.031253 & 0.024214 & -1.290692 & 0.2123 & \\
\hline \multirow[t]{2}{*}{$\mathrm{FISI}_{t}$} & FİSİ(-1) & 0.161550 & -0.307824 & 0.153030 & -2.011522 & 0.0573 & \multirow[t]{2}{*}{0.2801} \\
\hline & $\mathrm{C}$ & & 0.146260 & 0.073237 & 1.997078 & 0.0589 & \\
\hline
\end{tabular}

Note: Calculated by the authors using the eViews software package.

Table 8

When the time series of some indicators is both cross-sectional and "inclined"

\begin{tabular}{|c|c|c|c|c|c|c|c|}
\hline & & $\begin{array}{c}\text { R- } \\
\text { squared }\end{array}$ & coefficient & Std. error & t-statistics & probability & MacKinnon one-sided p-price \\
\hline \multicolumn{8}{|c|}{ Azerbaijan } \\
\hline \multirow[t]{5}{*}{$\mathrm{POV}_{t}$} & $\mathrm{POV}(-1)$ & \multirow[t]{5}{*}{0.540587} & -0.203142 & 0.119597 & -1.698547 & 0.1076 & \multirow[t]{5}{*}{0.7174} \\
\hline & $\mathrm{D}(\mathrm{POV}(-1)$ & & 1.002252 & 0.252762 & 3.965196 & 0.0010 & \\
\hline & $\mathrm{D}(\mathrm{POV}(-2)$ & & $\begin{array}{l}-0.788669 \\
\end{array}$ & 0.410490 & -1.921284 & 0.0716 & \\
\hline & $\mathrm{C}$ & & -154.7092 & 143.1797 & -1.080525 & 0.2950 & \\
\hline & trend & & 40.70812 & 19.40700 & 2.097599 & 0.0512 & \\
\hline \multirow[t]{3}{*}{$\mathrm{FiDi}_{t}$} & Fídi்'(-1) & \multirow[t]{3}{*}{0.503010} & -0.225075 & 0.120030 & -1.875155 & 0.0754 & \multirow[t]{3}{*}{0.6345} \\
\hline & $\mathrm{C}$ & & -0.003036 & 0.016199 & -0.187450 & 0.8532 & \\
\hline & trend & & 0.003697 & 0.000841 & 4.394829 & 0.0003 & \\
\hline \multirow[t]{3}{*}{$\overline{\mathrm{FIEI}}_{t}$} & FİĖं(-1) & \multirow{3}{*}{0.651958} & $\begin{array}{l}-0.932671 \\
\end{array}$ & 0.158788 & -5.873670 & 0.0000 & \multirow[t]{3}{*}{0.0004} \\
\hline & $\mathrm{C}$ & & 0.144475 & 0.035519 & 4.067568 & 0.0006 & \\
\hline & & & -0.007391 & 0.002005 & -3.686627 & 0.0015 & \\
\hline \multicolumn{8}{|c|}{ Turkey } \\
\hline \multirow[t]{3}{*}{$\mathrm{POV}_{t}$} & POV(-1) & \multirow[t]{3}{*}{0.098568} & -0.240148 & 0.164931 & $\begin{array}{l}-1.456053 \\
\end{array}$ & 0.1602 & \multirow[t]{3}{*}{0.8164} \\
\hline & $\mathrm{C}$ & & 474.2778 & 294.4496 & 1.610727 & 0.1222 & \\
\hline & trend & & 61.44543 & 50.61182 & 1.214053 & 0.2382 & \\
\hline \multirow[t]{3}{*}{$\mathrm{FIDI}_{t}$} & Fİİ(-1) & \multirow[t]{3}{*}{0.230081} & -0.162562 & 0.110358 & -1.473043 & 0.1563 & \multirow[t]{3}{*}{0.8093} \\
\hline & $\mathrm{C}$ & & 0.019739 & 0.015782 & 1.250735 & 0.2255 & \\
\hline & trend & & 0.001921 & 0.000877 & 2.188827 & 0.0406 & \\
\hline \multicolumn{8}{|c|}{ Iran } \\
\hline \multirow[t]{3}{*}{$P^{P O V_{t}}$} & POV(-1) & \multirow[t]{3}{*}{0.092630} & -0.198425 & 0.139667 & -1.420697 & 0.1701 & \multirow[t]{3}{*}{0.8281} \\
\hline & $\mathrm{C}$ & & 162.4261 & 128.7298 & $\begin{array}{l}1.261760 \\
\end{array}$ & 0.2209 & \\
\hline & trend & & 20.90386 & 19.07524 & 1.095863 & 0.2855 & \\
\hline
\end{tabular}




\begin{tabular}{|c|c|c|c|c|c|c|c|}
\hline \multirow[t]{3}{*}{$F \dot{\mathrm{I} D} \dot{\mathrm{I}}_{t}$} & Fİİ(-1) & 0.341989 & 0.338558 & 0.267436 & 1.265941 & 0.2201 & \multirow[t]{3}{*}{0.9999} \\
\hline & $\mathrm{C}$ & & -0.062203 & 0.038841 & -1.601467 & 0.1250 & \\
\hline & Trend & & -0.001316 & 0.003523 & -0.373506 & 0.7127 & \\
\hline$F \dot{\mathrm{I}} S \dot{\mathrm{I}}_{t}$ & FİSİ(-1) & 0.652523 & -1.822075 & 0.379274 & -4.804113 & 0.0002 & 0.0051 \\
\hline
\end{tabular}

Note: Calculated by the authors using the eViews software package.

However, the fact that the time series characterizing the indicators involved in the study are not stationary does not mean that the relationship between these indicators and $P O V_{t}$ is "spurious". Thus, if the stationarity of the $\varepsilon_{i t}$ residues in the regression between these indicators is confirmed, then the regression can be approached as a "true" relationship. Therefore, we will need to check the stationarity of the $\varepsilon_{i t}$ residues in regression with F-significance less than 0.05 in Tables 3,4 , and 5 . If the time series of the $\varepsilon_{i t}$ residues for such regression is stationary, then we can claim that the indicators in the single regression are cointegrated. We will apply ADF test for the stationarity of $\varepsilon_{i t}$ residues on all single regression

$$
\hat{\varepsilon}_{i, t}=\gamma * \hat{\varepsilon}_{i, t-1}+v_{t}
$$

Here $\hat{\boldsymbol{\varepsilon}}_{i, t}$ can be expressed as one of the following identities:

$$
\left\{\begin{array}{c}
\hat{\varepsilon}_{i t}=y_{i t}-\mathrm{b} * x_{i t} \\
\hat{\varepsilon}_{i t}=y_{i t}-\mathrm{b} * x_{i t}-c \\
\hat{\varepsilon}_{i t}=y_{i t}-\mathrm{b} * x_{i t}-\mathrm{c}-\delta * \mathrm{t}
\end{array}\right.
$$

Table 9

\section{Critical values $\left(\tau_{c}\right)$ for the cointegration test}

\begin{tabular}{|l|c|c|c|}
\hline & $1 \%$ & $5 \%$ & $10 \%$ \\
\hline 1) $\boldsymbol{y}_{\boldsymbol{t}}=\boldsymbol{\beta} * \boldsymbol{x}_{\boldsymbol{t}}+\boldsymbol{\varepsilon}_{\boldsymbol{t}}$ & -3.39 & -2.76 & -2.45 \\
\hline 2) $\boldsymbol{y}_{\boldsymbol{t}}=\boldsymbol{\beta}_{\mathbf{1}}+\boldsymbol{\beta}_{\mathbf{2}} * \boldsymbol{x}_{\boldsymbol{t}}+\boldsymbol{\varepsilon}_{\boldsymbol{t}}$ & -3.96 & -3.37 & -3.07 \\
\hline 3) $\boldsymbol{y}_{\boldsymbol{t}}=\boldsymbol{\beta}_{\mathbf{1}}+\boldsymbol{\delta} * \boldsymbol{t}+\boldsymbol{\beta}_{\mathbf{2}} *$ & -3.98 & -3.42 & -3.13 \\
$\boldsymbol{x}_{\boldsymbol{t}}+\boldsymbol{\varepsilon}_{\boldsymbol{t}}$ & & & \\
\hline
\end{tabular}

Source: Davidson and MacKinnon (1994) [24]

Since the regression relationship we use corresponds to the equation $y_{t}=\beta_{1}+\beta_{2} * x_{t}+\varepsilon_{t}$, we use for $1 \%$ significance (-3.96), for $5 \%$ significance $(-3.37)$, and for $10 \%$ significance $(-3.07)$. Based on the results of the ADF testing for the stationarity of $\varepsilon_{i t}$ residues, it can argue that 1) the residuals of the regression relationship between $\mathrm{POV}_{t}-\mathrm{FIDI}_{t}$ and $\mathrm{POV}_{t}-\mathrm{FIEI}_{t}$, which have a strong relationship for Azerbaijan, are not stationary; 2) As well as the residuals of regression between $\mathrm{POV}_{t}-\mathrm{FIDI}_{t}$, which is a strong for Turkey, are not stationary; 3 ) The residuals of the regression between $\mathrm{POV}_{t}-\mathrm{FIDI}_{t}$ and $\mathrm{POV}_{t}-\mathrm{FISI}_{t}$, which has a strong regression for Iran, are also not stationary.

Table 10

\begin{tabular}{|c|c|c|c|c|c|}
\hline & \multicolumn{2}{|c|}{ Azerbaijan } & Turkey & \multicolumn{2}{|c|}{ Iran } \\
\hline & $\begin{array}{l}\mathrm{POV}_{t} \\
-\mathrm{FIDI}_{t}\end{array}$ & $\begin{array}{l}\mathrm{POV}_{t} \\
-\dot{F I E I}_{t}\end{array}$ & $\mathrm{POV}_{t}-\mathrm{FIDI}_{t}$ & $\mathrm{POV}_{t}-\mathrm{FIDI}_{t}$ & $\mathrm{POV}_{t}-\mathrm{FISI}_{t}$ \\
\hline$\hat{\boldsymbol{\varepsilon}}_{i, t}=\gamma * \hat{\boldsymbol{\varepsilon}}_{i, t-1}+\boldsymbol{v}_{\boldsymbol{t}}$ & & & & & \\
\hline $\mathrm{R}$-square & 0.327945 & 0.192916 & 0.125657 & 0.356930 & 0.202593 \\
\hline$\gamma$ & -0.181555 & -0.326302 & -0.307429 & -0.255338 & -0.421448 \\
\hline Std. error & 0.121977 & 0.139181 & 0.170751 & 0.137122 & 0.175078 \\
\hline t-statistics & -1.488439 & -2.344436 & -1.800451 & -1.862130 & -2.407204 \\
\hline probability & 0.1522 & 0.0285 & 0.0855 & 0.0773 & 0.0249 \\
\hline MacKinnon is one-sided p-value & 0.1247 & 0.0214 & 0.0688 & 0.0608 & 0.0185 \\
\hline
\end{tabular}

ADF testing for stationarity of $\varepsilon_{i t}$ residuals

Note: Calculated by the authors using the eViews software package

Table 11

Dependence of $(\Delta \mathrm{POV})$ on Azerbaijan financial system development indices $\left(\Delta \mathrm{POV} t=a_{i 0}+a_{i 1} * \Delta X_{t}\right.$

\begin{tabular}{|c|c|c|c|c|}
\hline \multicolumn{5}{|c|}{$\left.\boldsymbol{+ \varepsilon}_{\boldsymbol{i t}}\right)$} \\
\hline$R^{2}$ & $\Delta \mathrm{FI} \dot{\mathrm{I}}_{t}$ & $\Delta \dot{\mathrm{F}}_{t}$ & $\Delta \mathrm{FIE} \dot{\mathrm{I}}_{t}$ & $\Delta \mathrm{FiS}_{t}$ \\
\hline Number of observations & 0.015053 & 0.064806 & 0.001087 & 0.159249 \\
\hline F-significance & 11 & 23 & 23 & 23 \\
\hline$a_{i 0}$ & 0.719315 & 0.241104 & 0.881271 & 0.05925 \\
\hline ratio & 135.9418 & 96.52592 & 86.38192 & 99.26778 \\
\hline Standard error & 131.1915 & 60.49427 & 63.68986 & 57.0182 \\
\hline t-statistics & 1.036209 & 1.595621 & 1.35629 & 1.740984 \\
\hline p-price & 0.327143 & 0.125514 & 0.189411 & 0.096319 \\
\hline
\end{tabular}




\begin{tabular}{|c|c|c|c|c|}
\hline$a_{i 1}$ & \multicolumn{5}{|l|}{} \\
\hline ratio & -284.935 & -2542.25 & 154.8058 & -1633.7 \\
\hline Standard error & 768.2918 & 2107.418 & 1023.932 & 819.1377 \\
\hline t-statistics & -0.37087 & -1.20633 & 0.151188 & -1.99441 \\
\hline p-value & 0.719315 & 0.241104 & 0.881271 & 0.05925 \\
\hline
\end{tabular}

Note: Calculated by the authors

Because of no stationarity of the time series of the indicators between them we have analysed regressions, as well as because of no cointegration of the residuals we need to check regression between the first differences of these indicators. In the Table 11 there are the results of the single regression between first differences of the independent and dependent variables according to the equation (7).

According to the results from Table 11, there is not any relationship between first differences of the considered indicators. As well as such results have been obtained for the indicators on the Turkey financial system (Table 12).

Table 12

Dependence of $\left(\triangle \mathrm{POV}_{t}\right)$ on Turkey financial system development indices $\left(\Delta \mathrm{POV}_{t}=a_{i 0}+\right.$

\begin{tabular}{|c|c|c|c|c|}
\multicolumn{5}{|c|}{$\left.\boldsymbol{a}_{\boldsymbol{i 1}} * \boldsymbol{\Delta} \boldsymbol{X}_{\boldsymbol{t}}+\boldsymbol{\varepsilon}_{\boldsymbol{i t}}\right)$} \\
\hline$R^{2}$ & $\Delta \mathrm{FIAI}_{t}$ & $\Delta \mathrm{FiD}_{t}$ & $\Delta \dot{F I E I}_{t}$ & $\Delta$ FiSi $_{t}$ \\
\hline $\begin{array}{c}\text { Number of } \\
\text { observations }\end{array}$ & 13 & 23 & 23 & 23 \\
\hline F-significance & 0.254183 & 0.053787 & 0.021743 & 0.018819 \\
\hline$a_{i 0}$ & & & \\
\hline ratio & 178.8078 & 260.3219 & 185.2444 & 173.9339 \\
\hline Standard error & 184.4104 & 144.9651 & 130.1244 & 131.675 \\
\hline t-statistics & 0.969619 & 1.795755 & 1.423594 & 1.320933 \\
\hline p-price & 0.353074 & 0.086938 & 0.169253 & 0.200738 \\
\hline$a_{i 1}$ & \multicolumn{5}{|c|}{} \\
\hline ratio & 1230.326 & -10564.2 & 1282.341 & -2962.69 \\
\hline Standard error & 1022.609 & 9669.014 & 1876.995 & 4668.246 \\
\hline t-statistics & 1.203125 & -1.09258 & 0.683188 & -0.63465 \\
\hline p-value & 0.254183 & 0.286955 & 0.501957 & 0.532513 \\
\hline
\end{tabular}

Note: Calculated by the authors

We can observe a bit different results on Iran economy. According to the results from the Table 13, the annual change of the financial institution efficiency index $\left(\Delta \mathrm{F} \dot{\mathrm{I}} \dot{\mathrm{I}}_{t}\right)$ and annual change of the financial institutions stability index of Iran have strong negative impacts on poverty level.

Table 13

Dependence of $\left(\Delta \mathrm{POV}_{\boldsymbol{t}}\right)$ on Iran financial system development indices $\left(\Delta \mathrm{POV}_{t}=a_{i 0}+a_{i 1} * \Delta X_{t}\right.$

\begin{tabular}{|c|c|c|c|c|}
\hline \multicolumn{5}{|c|}{$\left.+\varepsilon_{i t}\right)$} \\
\hline & $\Delta \mathrm{F} \dot{\mathrm{I} A} \dot{\mathrm{I}}_{t}$ & $\Delta \mathrm{Fí}_{t}$ & $\Delta \mathrm{FIEI}_{t}$ & $\Delta$ FISII $_{t}$ \\
\hline $\mathrm{R}^{2}$ & 0.000309 & 0.005967 & 0.38109 & 0.444873 \\
\hline $\begin{array}{c}\text { Number of } \\
\text { observations }\end{array}$ & 13 & 23 & 23 & 23 \\
\hline $\begin{array}{c}\text { F- } \\
\text { significance }\end{array}$ & 0.954549 & 0.726099 & 0.0017 & 0.000509 \\
\hline \multicolumn{5}{|l|}{$a_{i 0}$} \\
\hline ratio & 113.9105 & 76.20071 & 98.37869 & 101.351 \\
\hline $\begin{array}{c}\text { Standard } \\
\text { error }\end{array}$ & 122.6487 & 73.83247 & 51.55547 & 48.85788 \\
\hline t-statistics & 0.928754 & 1.032076 & 1.90821 & 2.074405 \\
\hline p-price & 0.372948 & 0.313777 & 0.070129 & 0.050526 \\
\hline \multicolumn{5}{|l|}{$a_{i 1}$} \\
\hline ratio & -142.722 & 634.2105 & -4468.04 & -1559.12 \\
\hline $\begin{array}{l}\text { Standard } \\
\text { error }\end{array}$ & 2447.746 & 1786.297 & 1242.532 & 380.0567 \\
\hline t-statistics & -0.05831 & 0.355042 & -3.59591 & -4.10234 \\
\hline p-value & 0.954549 & 0.726099 & 0.0017 & 0.000509 \\
\hline
\end{tabular}

Note: Calculated by the authors

But even such relationship needs to be tested by stationarity of time series of $\Delta \mathrm{FIEI}_{t}, \Delta \mathrm{FISI} \dot{I}_{t}$, and $\Delta \mathrm{POV}_{t}$ for Iran.

The calculations prove that time series of these indicators have stationarity and the regression results of the Table 13 are true and we can argue that only in Iran where applying Islamic banking the annual changes of the financial system efficiency and stability indicators have strong impacts on annual poverty level changes.

Without the "intersection" and "inclination" of the time series of some indicators

Table 14 $\left(\Delta\left(\Delta y_{t}\right)=\beta * \Delta y_{t-1}+\gamma * \Delta\left(\Delta y_{t-1}\right)+v_{t}\right)$ results

\begin{tabular}{|c|c|c|c|c|c|c|c|}
\hline & & R-squared & coefficient & Std.error & t-statistics & probability & $\begin{array}{c}\text { MacKinnon } \\
\text { one-sided p- } \\
\text { price }\end{array}$ \\
\hline \multicolumn{8}{|c|}{ İran } \\
\hline$\Delta \mathrm{POV}_{t}$ & $\triangle \mathrm{POV}(-1)$ & 0.367214 & -0.734151 & 0.205467 & -3.573090 & 0.0017 & 0.0010 \\
\hline \multirow[t]{2}{*}{$\Delta \mathrm{FIEI} \dot{I}_{t}$} & $\Delta$ FİEİ(-1) & 0.856513 & -2.399740 & 0.387080 & -6.199601 & 0.0000 & \multirow[t]{2}{*}{0.0000} \\
\hline & $\mathrm{D}(\mathrm{D}$ (FİEİ(-1)) & & 0.443826 & 0.212302 & 2.090540 & 0.0502 & \\
\hline
\end{tabular}




\begin{tabular}{|c|c|c|c|c|c|c|c|}
\hline \multirow[t]{3}{*}{$\Delta \mathrm{FISI}_{t}$} & $\Delta \mathrm{FİSI}(-1)$ & \multirow[t]{3}{*}{0.721547} & -2.173785 & 0.520091 & -4.179627 & 0.0006 & \multirow[t]{3}{*}{0.0003} \\
\hline & $\Delta(\Delta \mathrm{FİSI}(-1))$ & & 0.788904 & 0.416571 & 1.893802 & 0.0754 & \\
\hline & $\Delta(\Delta \mathrm{FİSI}(-2))$ & & 0.614164 & 0.249236 & 2.464185 & 0.0247 & \\
\hline
\end{tabular}

Note: Calculated by the authors

Table 15

Some indicators are "intersecting" in the time series of stationary, but without "inclination" $\left(\Delta\left(\Delta y_{t}\right)=\right.$

\begin{tabular}{|c|c|c|c|c|c|c|c|}
\hline \multicolumn{8}{|c|}{$\left.\alpha+\beta * \Delta y_{t-1}+\gamma * \Delta\left(\Delta y_{t-1}\right)+v_{t}\right)$ results } \\
\hline & & $\begin{array}{c}\mathrm{R}- \\
\text { squared }\end{array}$ & coefficient & Std.error & $\begin{array}{c}\mathrm{t}- \\
\text { statistics }\end{array}$ & probability & $\begin{array}{l}\text { MacKinnon one-sided p- } \\
\text { price }\end{array}$ \\
\hline \multicolumn{8}{|r|}{ 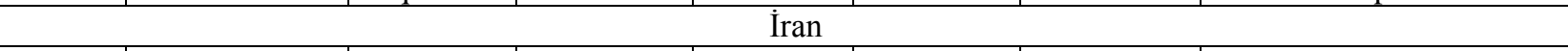 } \\
\hline \multirow[t]{2}{*}{$\Delta \mathrm{POV}_{t}$} & $\triangle \mathrm{POV}(-1)$ & 0.398538 & -0.797410 & 0.213767 & $\begin{array}{c}- \\
3.730274\end{array}$ & 0.0012 & \multirow[t]{2}{*}{0.0105} \\
\hline & $\mathrm{C}$ & & 69.89744 & 66.83632 & 1.045800 & 0.3075 & \\
\hline \multirow[t]{3}{*}{$\Delta \mathrm{FIEI} \dot{I}_{t}$} & $\Delta$ Fíìi(-1) & 0.858808 & -2.410151 & 0.394963 & $\begin{array}{c}- \\
6.102213\end{array}$ & 0.0000 & \multirow[t]{3}{*}{0.0001} \\
\hline & $\begin{array}{l}\mathrm{D}(\mathrm{D} \text { (FİDİ(- } \\
1))\end{array}$ & & 0.448972 & 0.216578 & 2.073032 & 0.0528 & \\
\hline & $\mathrm{C}$ & & 0.003757 & 0.006946 & 0.540849 & 0.5952 & \\
\hline \multirow[t]{4}{*}{$\Delta \mathrm{FISI}_{t}$} & $\Delta$ Fisi(-1) & 0.773458 & -2.688882 & 0.553342 & $\begin{array}{c}- \\
4.859348\end{array}$ & 0.0002 & \multirow[t]{4}{*}{0.0011} \\
\hline & $\Delta(\Delta \mathrm{FISI}(-1))$ & & 1.141761 & 0.428910 & 2.662007 & 0.0170 & \\
\hline & $\Delta(\Delta \mathrm{FI} \dot{S} \dot{I}(-2))$ & & 0.758365 & 0.243656 & 3.112445 & 0.0067 & \\
\hline & $\mathrm{C}$ & & 0.054448 & 0.028436 & 1.914780 & 0.0736 & \\
\hline
\end{tabular}

Table 16

When the time series of some indicators is both cross-sectional and "inclined" $\left(\Delta\left(\Delta y_{t}\right)=\alpha+\lambda * t+\beta *\right.$ $\left.\Delta y_{t-1}+\gamma * \Delta\left(\Delta y_{t-1}\right)+v_{t}\right)$ results

\begin{tabular}{|c|c|c|c|c|c|c|c|}
\hline & & $\begin{array}{c}\text { R- } \\
\text { squared }\end{array}$ & coefficient & Std.error & t-statistics & probability & $\begin{array}{l}\text { MacKinnon } \\
\text { one-sided p- } \\
\text { price }\end{array}$ \\
\hline \multicolumn{8}{|c|}{ İran } \\
\hline \multirow{3}{*}{$\triangle P O V_{t}$} & $\Delta \mathrm{POV}(-1)$ & \multirow[t]{3}{*}{0.402077} & -0.802304 & 0.218863 & -3.665773 & 0.0015 & \multirow[t]{3}{*}{0.0459} \\
\hline & $\mathrm{C}$ & & 111.1815 & 138.0623 & 0.805299 & 0.4301 & \\
\hline & trend & & -3.404254 & 9.894556 & -0.344053 & 0.7344 & \\
\hline \multirow[t]{4}{*}{$\Delta F \dot{\mathrm{I}} E \dot{\mathrm{I}}_{t}$} & $\Delta$ FİĖं(-1) & \multirow[t]{3}{*}{0.860570} & -2.414552 & 0.403982 & -5.976887 & 0.0000 & \multirow[t]{4}{*}{0.0005} \\
\hline & $\Delta(\Delta \mathrm{F} \dot{\mathrm{IEI}}(-1))$ & & 0.451338 & 0.221520 & 2.037459 & 0.0575 & \\
\hline & $\mathrm{C}$ & & -0.002758 & 0.015748 & -0.175134 & 0.8630 & \\
\hline & Trend & & 0.000543 & 0.001172 & 0.463521 & 0.6489 & \\
\hline \multirow{5}{*}{$\Delta F \dot{\mathrm{I} S} \dot{\mathrm{I}}_{t}$} & $\Delta$ Fİं்i(-1) & \multirow[t]{5}{*}{0.781956} & -2.898552 & 0.624140 & -4.644072 & 0.0003 & \multirow[t]{5}{*}{0.0075} \\
\hline & $\mathrm{D}(\mathrm{D}$ (FISİ(-1))) & & 1.294941 & 0.478545 & 2.705994 & 0.0163 & \\
\hline & $\mathrm{D}(\mathrm{D}$ (Físí(-2))) & & 0.826989 & 0.262691 & 3.148147 & 0.0066 & \\
\hline & $\mathrm{C}$ & & 0.013173 & 0.061192 & 0.215275 & 0.8325 & \\
\hline & trend & & 0.003719 & 0.004864 & 0.764578 & 0.4564 & \\
\hline
\end{tabular}

Note: Calculated by the authors

\section{Discussion}

This study proves that the socio-economic impact of Islamic banking, including the impact on poverty, differs from that of traditional banks. The existence of conceptual differences between traditional and Islamic banking should be reflected in the nature of the socio-economic effects of such different systems. Thus, according to Burhanuddin [19], Islamic banking creates a synergistic effect in its activities by adhering to the principles of fairness and expediency. According to research by Beck et al.[8] and Hasan \& Dridi [20], Islamic banks are more stable than traditional banks, and therefore their advantages are felt during financial crises. Our study also proves that result. The distribution of income in Islamic banks is fairer than in traditional banks, where the principle of usury prevails. Such a distribution applies not only to the reduction of income from banking activities, but 
also to the reduction of inequality in the distribution of public finances [21]. A study of the socioeconomic impact of the banking sector on the example of Indonesia leads to the conclusion that the role of Islamic banks in poverty reduction is less than that of traditional banks [22]. Given the introduction of a dual banking system in Indonesia, Setiawan [22] used the 2SLS (two stage least squares method) method to compare the impact of the development of both banking systems on poverty. However, the study emphasizes the important role of Islamic banks in economic and socio-economic development.

\section{Conclusion}

In this study there were used new indices for comparative analyses of financial development aspects of three Islamic countries and their impacts on poverty. The financial systems with Islamic banking have more stability index in compare with the financial systems where applying traditional banking. As well as in Azerbaijan where is applying only traditional banking, and in Turkey where is applying Islamic banking in small scope together with traditions banking the financial system has not any impact on poverty level. In contrast, the financial system of Iran with Islamic banking has strong negative impacts on poverty rate.

\section{References:}

[1] McKinnon, R.I. "Money and Capital in Economic Development", The Brookings Institution Press, Washington DC. 1 March 1973, p. 184.

[2] Shaw, E. "Financial Deepening in Economic Development", Oxford University Press, New York. 1973, p. 260.

[3] Pagano, M. "Financial markets and growth: an overview", European Economic Review, Vol. 37 Nos 2/3, 1993, pp. 613-622.

[4] Berthelemy, J.C. and Varoudakis, A. "Economic growth, convergence clubs, and the role of financial development", Oxford Economic Papers, Vol. 48 No. 2, 1996, pp. 300-328.

[5] Jalilian, H. and Kirkpatrick, C. "Does financial development contribute to poverty reduction?", Journal of Development Studies, Vol. 41 No. 4, 2005, pp. 636-656, available at: https://doi.org/10.1080/ 00220380500092754

[6] Jeanneney, S.G. and Kpodar, K. "Financial development and poverty reduction: can there be a benefit without cost?", Journal of Development Studies, Vol. 47 No. 1, 2008, pp.
143-163, available at: https://doi.org/10.1080/00220388.2010.506918

[7] Quartey, P. "Financial sector development, savings mobilisation and poverty reduction in Ghana", UNU-WIDER United Nations University, Helsinki.Research Paper No. 2005/71, 2005, $31 \mathrm{p}$.

[8] Beck, T., Demirgüç-Kunt, A. and Levine, R. "Finance, inequality and the poor", Journal of Economic Growth, Vol. 12 No. 1, 2007, pp. 2749.

[9] Honohan, P. and Beck, T. "Making Finance Work for Africa", World Bank, Washington, DC. 2007, p.264

[10] Todaro, M.P. "Economic Development", Addison-Wesley, Reading, MA., 12th Edition 2015, p. 896

[11] Honohan, P. "Financial Development, Growth and Poverty: How Close are the Links?" Policy Research Working Paper Series 3203. The World Bank. 2004, p.31.

[12] Perez-Moreno, S., 2011. Financial development and poverty in developing coun- tries: a causal analysis. Empir. Econ. 41, 2004, pp.57-80.

[13] Donou-Adonsou, F., Sylwester, K. "Financial development and poverty reduction in developing countries: new evidence from banks and microfi- nance institutions". Rev. Dev. Financ. 6, 2016, pp.82-90.

[14] Mookerjee, R., Kalipioni, P., "Availability of financial services and income inequality: the evidence from many countries". Emerg. Mark. Rev. 11, 2010, pp.404-408.

[15] Akhter, S., Daly, K. "Finance and poverty: evidence from fixed effect vector decomposition". Emerg. Mark. Rev. 10, 2009, pp.191-206.

[16] Guillaumont Jeanneney, S., Kpodar, K., "Financial development and poverty reduction: can there be a benefit without a cost?" J. Dev. Stud. 47, 2011, 143-163.

[17] Sanusi, L. S. "Banking Reforms and Its Impact on the Nigeria Economy; Being a Lecture Delivered at Warwick's Economic Summit, UK on $17^{\text {th }}$ February, 2012, pp.1-7

[18] Gazi Salah Uddin, Phouphet Kyophilavong, Nasim Sydee. "The Casual Nexus of Banking Sector Development and Poverty Reduction in Bangladesh". International Journal of Economics and Financial Issues Vol. 2, No. 3, 2012, pp.304-311.

[19] Burhanuddin Abdullah. Peran Kebijakan Moneter dan Perbankan Dalam Mengatasi Krisis Ekonomi di Indonesia, Bahan Kuliah 
Kursus Reguler Angkatan XXXVI Lemhanas Tanggal, Jakarta, 13 Juni, 2003, pp.187-200

[20] Hasan, Maher and Jemma Dridi. "The Effects of the Global Crisis on Islamic and Conventional Banks: A Comparative Study", International Monetary Fund WP/10/201, 2010, p.47.

[21] Chapra, Umer. "The Case Against Interest: Is It Compelling?" Thunder Bird International Business Review, Wiley Periodicals.Vol: 49, 2007, pp. 161-186,

[22] Setiawan İwan. "Role of Islamic Banking and Conventional Against Poverty with The Dual Banking System". MIMBAR, 2016, Vol. 32, No. 2nd (December, 2016), pp. 353-361

[23] Hamilton, J. "Time series analysis". Princeton University Press, 1994, p.766

[24] Onwuka, I. O., Nwadiubu. "Effect of Financial Sector Development on Poverty Alleviation The Nigerian Experience (1986 - 2018)". Advances in Social Sciences Research Journal, 6(6) 2019, pp. 39-51.

[25] Xiaohua Duan, Systematic Risk Measurement Based on CoVaR Model, International Journal of Circuits, Systems and Signal Processing, Volume 13, 2019, pp. 243-250,

[26] Zhuo Zhang, Jia Wang, Financial Model based on Principle Component Analysis and Support Vector Machine, International Journal of Circuits, Systems and Signal Processing, Volume 13, 2019, pp. 183-190,

[27] Gulaliyev, M.G., Ashurbayli-Huseynova, N.P., Gubadova, A.A., Ahmedov, B.N., Mammadova, G.M., Jafarova, R.T. Stability of the banking sector: deriving stability indicators and stresstesting, "Polish Journal of Management Studies', 19 (2), 2019, pp. 182-195.

\section{Creative Commons Attribution License 4.0 (Attribution 4.0 International, CC BY 4.0)}

This article is published under the terms of the Creative Commons Attribution License 4.0

https://creativecommons.org/licenses/by/4.0/deed.en_US 